\title{
Do the Educational Content and Activities of Action Pack Textbook Involve Jordanian EFL Fifth-Grade Students in Learning English Language? An Analytical Study
}

\author{
Yaser Aladwan \\ Language Center, the World Islamic Sciences and Education University, Amman, Jordan
}

\begin{abstract}
The current study aimed at analyzing the degree of involvement of the educational content and activities in Action Pack 5, which is used to teach the English language for Jordanian students in grade five. To gather the data, the researcher used Romey's formula. To achieve the study purposes, 25\% of Action Pack textbook pages were chosen randomly to find out the level of involvement of the educational content. Also, all the activities, totaling (122) activities were chosen from the analyzed textbook to find out the level of involvement in these activities. Results showed that the degree of involvement of the educational content of Action Pack 5 was (0.19), which means that the analyzed textbook was autocratic and had few challenges that evoke students' thoughts. It also shows that the degree of involvement of the analyzed activities was (0.87), which means that the analyzed textbook makes students in grade five more involved and active during their learning English.
\end{abstract}

Index Terms-Action Pack 5, English language textbook, fifth-grade students, involvement

\section{INTRODUCTION}

Textbooks are one of the key parts of any educational system. They are considered the source of knowledge, information, and facts. Therefore, teachers can present the learning material to their students. The English language is one of the main school subjects, so it is important to be interested in the educational content that is found in English textbooks. In Jordan, Action Pack 5 is used to teach the English language to students who are in fifth grade.

Teaching and learning the English language require using a textbook that is written and organized correctly (Pamungkas, 2010). It is claimed that the content of any textbook should be presented in a manner that facilities achieving the outcomes of the textbook, and in turn improving students' performance academically and personally. Thus, introducing the educational content is needed to achieve the purposes of the learning process (Sa'ada \& Ibrahim, 2011).

Different reasons make the textbook is so important. First, it presents experiential content, and it classifies the learning material rationally to reach the planned goals. Second, it introduces for both teachers and students what they are going to do to complete their teaching and learning processes (Eisner, 1994). It is clear that textbooks are significant in education and play a key role in it. Although presenting a suitable textbook is required, but analyzing it is also so important (Tanner \& Tanner, 1998).

The analysis of the textbook is based on clear criteria, such as the suitability of the textbook for students. According to Al-Hashemi and Al-Ghazawi (2006), using involvement as a standard of evaluating the textbook is one of the different ways. The use of involvement helps in investigating the suitability of the textbook for students' level and helps in exploring students' ability to use the learning material. Thus, introducing the textbook should be in a manner that allows students to be involved deeply in the learning process.

The involvement is defined as " the degree of attracting the textbook for students and involving them in the book material through presenting the educational material, including the activities and abstracts that stimulate students to explore and discover, and challenge their ideas to be more interactive" (Al-Naji, 2002, p. 77). Another definition of involvement is written by Suleiman (2003) who defined it as the level of the textbook in offering the information and the educational situations for students that are related to the learning milieu.

It can be said that the first person who assesses the involvement is Romey (1968). According to Romey (1968), the involvement degree of the textbook is measured by introducing the learning material as activities, drawings, and shapes. This process of evaluation can be made by selecting random pages from the textbook and then evaluating and analyzing them to discover the involvement level of the analyzed textbook (Abu Sa'aleek, 2018).

The content of the textbook should be in a manner that encourages students to be more engaged while they learn. This aspect of the content makes students more active and dynamic in the class (Fazlollahi \& Tavana, 2010). The content that makes students active has the following aspects (Romey, 1968; Delavar, 2007):

1. Giving students a key role in the learning process. 
2. Having questions that ask students to use a higher level of thinking.

3. Presenting activities that motivate students' thinking and encourage them to discover.

4. Asking students to deal with different views and select the appropriate one.

\section{REVIEW OF RELATED LITERATURE}

Alsirhani (2011) analyzed the texts of Arabic language textbooks used to teach grade 4 in Saudi Arabia. His study aims to find out the level of involvement of the analyzed texts. The researcher used Romey's formula to analyze the data. Results showed that the level of the involvement is suitable, and this means that the analyzed texts are involved students during learning the Arabic language.

Nawafleh (2012) analyzed the degree of involvement in science textbooks, which are used to teach students in grades 6,7 , and 8 in Jordan. Data was collected by Romey's formula. Findings showed that the analyzed activities have an acceptable level of involvement.

Yahia (2014) analyzed science textbooks to find out the level of involvement. These textbooks were used in Jordan to teach students who are in grades 1,2, and 3. Findings showed that the three textbooks are involved students during learning science.

Khalaf (2015) analyzed the degree of involvement in the science textbook in Jordan. This textbook is used to teach science to students who are in grade 4. After content analysis of the textbook was made, the finding showed that the analyzed activities do not involve fourth-grade students properly.

Fari (2016) analyzed the textbooks used to teach science for grades 6, 7, and 8 in Palestine. The purpose of the study is to find out the level of involvement in these textbooks. To gather the data, Romey's formula was used. Results showed that analyzed activities are not in an acceptable range, and this means that students are not involved in science class. Also, analyzing diagrams and pictures showed that they involve students in learning science.

Haji (2016) analyzed the content of the social studies textbook to find out the degree of involvement. The textbook is used for students who are in grade 6 in Kurdistan. Collecting data was based on using Romey's formula. Findings revealed that the analyzed activities are adequately involved students.

Eslaminejad and Saeid (2017) analyzed the English language textbook to find out the level of involvement. The textbook is used in Iran to teach the language to adult students. The researcher analyzed all the content of the textbook. Results showed that the textbook has a satisfactory level of involvement which means that the learning material of the book involved students in their learning the language.

Al-wa'elly (2017) investigated the degree of involvement in the Arabic language textbook. This textbook is used to teach grammar for Jordanian tenth-grade students. The researcher analyzed 74 activities to find out the involvement degree. Romey's formula was used to collect the data. Results showed that the activities are involved students according to the technique used (i.e., Romey's formula). They also showed that the involvement degree in the analyzed textbook is not in an adequate range that allows students to involve during learning the grammar.

Abu Sa'aleek (2018) analyzed the English language textbook to find out the level of involvement. The researcher analyzed 136 activities in the textbook " entitled Action Pack 12" used to learn the language in Jordan. Gathering data was based on Romey's formula. Results revealed that the learning material existing in the textbook is unsatisfactory while the degree of involvement of the analyzed activities is high.

Al-Mutairi (2020) analyzed the content of the Arabic language sixth-grade textbook to find out the level of involvement. Collecting the data was based on Romy's formula. Findings showed that presenting the content is satisfactory, which means that students are involved in the content. Also, findings showed that the activities are at an unsatisfactory level, which means they are not involved with students during their learning.

\section{SUMMARY}

It is clear from the reviewed studies that all studies were analyzed the level of involvement in the targeted textbooks. The researchers analyzed different school subjects, such as (Alsirhani, 2011; Al-wa'elly, 2017; Al-Mutairi, 2020) who analyzed the Arabic language textbooks. The study of (Nawafleh, 2012; Yahia, 2014; Khalaf, 2015; Fari, 2016) examined the degree of involvement in science textbooks. Moreover, the study of (Eslaminejad and Saeid, 2017; Abu Sa'aleek, 2018) analyzed the level of involvement in English language textbooks. Different textbooks for different grades were analyzed, such as (Alsirhani, 2011) analyzed fourth-grade textbook. The study of (Nawafleh, 2012; Fari, 2016; Al-Mutairi, 2020; Haji, 2016) analyzed the textbooks used to teach grades 6, 7, and 8. Also, the study of (Alwa'elly, 2017) analyzed the students' tenth-grade textbook. The study of (Abu Sa'aleek, 2018) analyzed the textbook used to teach tenth-grade students.

The present study seeks to analyze Action Pack 5 to find out the level of involvement. The current study differs from the reviewed studies because it analyzes Action Pack 5 which is a relatively new edition used in Jordan to teach English for students who are in grade 5. There are no, to the researcher's best knowledge, studies that analyzed the textbook, specifically under the study.

In the Jordanian context, students learn the English language through using the Action Pack series. This series is used to learn the language from grade 1 to 12. Students are given the English class either 4 or 5 times every week. English teachers are equipped with a teacher's book, flashcards, and CDs to teach the language naturally. The Ministry of Education (MoE) usually seeks to adapt the textbooks used to teach the English language, and this adaptation goes 
through vast developments around the world. Action Pack 5 is one of the new textbooks that can now be used to learn the English language. Thus, it is important to evaluate the activities used in the textbook and decide whether they involve students in their learning the language or not.

\section{STATEMENT OF THE PROBLEM}

It is believed that the textbook is one of the main parts of the teaching-learning process. Therefore, it is needed to revise the content of the textbook to present the educational content in a way that focuses on using higher thinking skills. Different experts are called to analyze the textbook before using it in teaching and learning. In Jordan, the MoE usually develops the textbook used in teaching the English language. One of these textbooks is Action Pack 5 which is considered the first textbook in the basic stage.

During the researcher's work in teaching the English language, he has strongly noticed that students have low performance in learning the language. This result is because the learning material is not presented in a way that students can easily get involved during learning the English language.

\section{PURPOSE OF THE STUDY}

The present study tries to find the involvement level in the analyzed educational content and activities in the textbook Action Pack 5.

\section{RESEARCH QUESTIONS}

1. What is the degree of involvement of the educational content used in Action Pack 5?

2. What is the degree of involvement of the activities used in Action Pack 5?

\section{SIGNIFICANCE OF THE STUDY}

This study is significant because it is the first study in Jordan that analyzed the English language textbook, namely Action Pack 5. Also, it is helpful for the authors of the textbook to provide them feedback about the degree of involvement in the analyzed textbook. This study is also useful because it provides a piratical framework for English supervisors regarding the involvement to give attention when they train teachers.

\section{LIMITATIONS OF THE STUDY}

This study is confined to the English language textbook (i.e., Action Pack 5), which is used to teach the language during the scholastic year 2021/2022. Also, it is limited to the involvement of the textbook in two domains (the educational content and the activities).

\section{OPERATIONAL DEFINITIONS OF TERM}

The Involvement: The degree to which students' fifth-grade interact with the content of Action Pack 5, and what it contains educational content and activities that stimulate students' thinking and encourage them to research and not only as a recipient of information. The involvement of the textbook is measured by Romy's formula.

Presenting the Educational Content: This is the way that is used by the authors of the Action Pack to present the educational content for grade 5 .

Activities: are the practical linguistic situations that enable the student to practice linguistic behavior inside and outside the school.

Action Pack 5: is the official textbook used in Jordan to teach and learn the English language for fifth-grade students.

\section{MethodOLOGY}

The present study tackled the descriptive-analytical research design to accomplish the purposes of the study. The researcher used Romey's formula to find out the level of involvement of the analyzed textbook (viz. Action Pack 5).

\section{POPULATION OF THE STUDY}

The researcher chose the Action Pack textbook as the population of the current study to find out the degree of involvement in the analyzed content and activities. This textbook was used to teach the English language to Jordanian fifth-grade students during the year 2021/2022. The researcher depends on the specific areas to analyze the textbook as follows:

1. The involvement of the textbook regards the presentation of the educational content.

2. The involvement of the textbook regards activities.

\section{SAMPLE OF THE STUDY}

The researcher chose a part of the textbook as the sample of the current study. In light of presenting the educational content, $25 \%$ of the textbook pages were chosen. Also, he chose all the activities, totaling (122) activities.

\section{INSTRUMENT OF THE STUDY}

This study was based on Romey's formula (1968) as the instrument of the study, which was used to collect and analyze the data. Romey's instrument can be summarized as follows:

First: The involvement of the textbook regards the presentation of the educational content

The educational content can classified into categories as follows: (a) facts; (b) conclusions or generalizations; (c) definitions ;(d) direct questions; (e) questions to ask students to analyze information; (f) declarative sentences; (g) instructions that ask students to perform an activity; (h) questions that are asked to interest students; (i) guided sentences; (j) rhetorical sentences. In light of this formula, the involvement of the textbook regards the presentation of the educational content is

The involvement coefficient $=(e, f, g, h) \div(a, b, c, d)$. 
Second: The involvement of the textbook regards activities.

To calculate the involvement of the activities in the analyzed textbook, the researcher followed the following formula: The number of suggested activities $\div$ The number of selected pages

Interpretation of coefficient values

According to Azar (1982), the following standards can be used to find out the level of involvement. These standards were as follows:

1. If the level of involvement is zero, this means that the textbook does not engage students while they learn.

2. If the level of involvement is (1), this means that only half of the sentences involve students and encourage them to think.

3. If the level of involvement is between $(0.4-1.5)$, which means that the content of the textbook makes students active while they learn.

4. If the level of involvement is less than (0.4), which means that the textbook has a simple challenge for the student's thought

5. If the level of involvement is more than (1.5), which means that the textbook has a question with little information on how to deal with these questions.

\section{RELIABILITY OF THE ANALYSIS}

Two methods were used to find out the reliability regards the presentation of the educational content. The first method was the analysis reliability of the researcher himself. In this method, the researcher reanalyzed the analysis of the educational content by selecting randomly five pages of the textbook pages. The researcher compared his analysis in the first and second after two weeks of finishing the first analysis. The percentage of the agreement of the two analyses was (82). The second method was made by making another analysis from another researcher after training her how to analyze the textbook based on Romey's formula. The percentage of the two analysis was (79), which it is adequate for the study.

\section{STATISTICAL ANALYSIS}

Romey's formula was used to find out the degree of involvement in the analyzed textbook. Frequencies and percentages were calculated to identify the level of involvement in the areas of the study (the educational content and the activities).

\section{RESULTS}

Results related to question one: What is the degree of involvement of the educational content used in Action Pack 5?

To find out the level of involvement in the analyzed educational content, the study sample was analyzed and classified under Romey's formula. Frequencies and percentages of each category were calculated. Results are shown in Table 1.

TABLE 1

FREQUENCIES AND PERCENTAge OF THE ANALYZED EdUCATIONAL CONTENT In ACTION PACK 5

\begin{tabular}{llll}
\hline Category & Sentences & Frequencies & Percentage \\
\hline A & Facts & 35 & 29 \\
B & conclusions or generalizations & 20 & 16 \\
C & Definitions & 13 & 10 \\
D & direct questions & 25 & 20 \\
E & analytical questions & 5 & 4 \\
F & declarative sentences & 12 & 10 \\
G & Instructions & - & - \\
H & questions that are asked to interest students & 1 & 1 \\
I & guide sentences & 7 & 6 \\
J & rhetorical sentences & 5 & 4 \\
& Total & 123 & $100 \%$ \\
Involvement degree of the textbook & 0.19 & \\
\hline
\end{tabular}

As shown in Table1, the degree of involvement of the Action Pack 5 textbook was (0.19). This result shows that Action Pack 5 which is used to teach the English language for grade 5 has simple challenges that stimulate student's thoughts.

Results related to question two: What is the degree of involvement of the activities used in Action Pack 5?

The researcher counted all the activities in the analyzed textbook (namely Action Pack 5). To find out the level of involvement of the activities, the following formula was used. The degree of involvement of the activities $=$ The number of suggested activities (122) $\div$ The number of selected pages $(139)=0.87$. Table 2 shows the title of units and the number of the proposed activities. 
TABLE 2

UNIT TITLES AND THEIR NUMBER OF ACTIVITIES IN ACTION PACK 5 ENGLISH TEXTBOOK

\begin{tabular}{lll}
\hline Unit Number & Unit Title & Number of Activities \\
\hline 1 & We usually go to the park & 7 \\
2 & The moon was a circle & 7 \\
3 & Did you enjoy school today? & 6 \\
4 & Review & 7 \\
5 & Are you going to see planes? & 7 \\
6 & Grandpa took this photo & 7 \\
7 & She is the youngest in the family & 7 \\
8 & What were you doing? & 7 \\
9 & Review & 7 \\
10 & Are there any lentils? & 7 \\
11 & The meal tastes delicious! & 6 \\
12 & Why is Kareem excited? & 7 \\
13 & Review & 7 \\
14 & You should play sports & 7 \\
15 & There was a great celebration! & 7 \\
16 & Life will be different & 5 \\
17 & Have you ever climbed a mountain? & 122 \\
18 & Review & \\
Total & 18 &
\end{tabular}

As shown in Table2, the number of the analyzed activities was (122) and the number of textbook pages was (139). The degree of involvement was (0.87), which is acceptable if it is located between $(0.4-1.5)$.

\section{DISCUSSION}

\section{Discussion of the Results Related to Question One}

The results show that the degree of involvement of the educational content $(0.19)$, and is a very low percentage according to Romey's formula. This result indicated that the analyzed textbook is so autocratic and does not allow opportunities for students to participate actively. This confirms that the textbook which is used to teach English for grad five has educational content focusing on facts, generalizations, and conclusions. The researcher explains these results to that the textbook is based on the language directly and neglecting the importance of improving students' thinking skills and their needs to research and find the information by themselves. It can be seen from the analysis that the textbook has educational content (i.e., facts and generalizations). This indicates that the textbook has ignored utilizing the content which focuses on skills, such as problem-solving and critical thinking. The researcher may due to this result to that the authors of the textbook have little knowledge of the significance of involvement because they may learn in the conventional methods or may respond to norms that affect writing the educational content of Action Pack 5. Also, this result may be because the authors of the textbook are foreign, who do not know the nature of Arab students and their needs. The results of the study are congruent with the results of the study (Khalaf, 2015; Fari, 2016; Haji, 2016; Alwa'elly, 2017; Abu Sa'aleek, 2018) who indicated in their findings that the degree of involvement of the educational content is very low percentage and unacceptable according to Romey's formula. In contrast, the results of the current study are incongruent with the studies (Alsirhani, 2011; Nawafleh, 2012; Yahia, 2014; Eslaminejad and Saeid, 2017; Al-Mutairi, 2020) who indicated in their results that the analyzed textbooks have an acceptable level of involvement.

\section{Discussion of the Results Related to Question Two}

The results of the analysis showed that the level of involvement in the analyzed activities was (0.87). This percentage is satisfactory according to Romey's formula. Action Pack textbook for grade five presented linguistic activities that allow students to participate and activate freely and encourage them to self-learning. This result may be since the analyzed textbook has given interest for the assessment tools and activities. To achieve the purposes of the textbook, the activities are comprehensive that cover questions in different levels (i.e., comprehension, analysis, evaluation, and improving students' linguistic repertoire).

Because of the importance of the English language, the authors of the textbook present varied activities that ask students to respond to them either orally or in writing. The diversity of the activities helped the authors to enrich the textbook with different activities that make students the core of the teaching/learning process and make them autonomous learners. The findings of the current study go with the findings in studies (Fari, 2016; Haji, 2016; Eslaminejad and Saeid, 2017; Al-wa'elly, 2017; Abu Sa'aleek, 2018) who show in their analysis that the analyzed textbooks have activities that involved students while the findings of the present study do not go with the findings with studies (Khalaf, 2015; Al-Mutairi, 2020) who that their analyzed textbooks do not have activities that involve and makes students activate during their learning.

\section{CONCLUSION}

Based on the results of the analysis of involvement degree in Action Pack 5, several recommendations are presented:

1. Presenting the educational content in a way that stimulates students' thinking and encourages them to acquire selflearning skills. 
2. Summarizing the learning material at the end of every unit to help students complete their learning and inspire them to investigate and analyze.

3. Increasing teachers' awareness about students' involvement in the teaching-learning process.

4. Conducting other research to find out the degree of involvement in other English language textbooks in Jordan.

\section{REFERENCES}

[1] Abu Sa'aleek, R. (2018).The Involvement of the Twelfth Grade English Textbook in Jordan: An Analytical Study. Indonesian Research Journal in Education, 2(2), 75-85.

[2] Al-Hashemi, A., \& Al-Ghazawi, F. (2006). Studies in Arabic language curricula and teaching methods. Dar Al-Waraq for publishing and distribution, Jordan.

[3] Al-Mutairi, S. (2020). The degree of the involvement of student in the Arabic language book for the sixth grade in the state of Kuwait (Unpublished master's thesis). Al-Albayt University, Al- Mafraq, Jordan.

[4] Al-Naji, H. (2002). Level of reading and the degree of involvement of the Arabic language book for the sixth grade in the United Arab Emirates. Seminar on curriculum-foundations and principles, college of education, King Saud University, 19 (20), pp. 515-552.

[5] Alsirhani, A. (2011). The readability level and degree of involvement of the texts of Arabic language textbook of the fourth grade in Saudi Arabia. Unpublished Master Thesis, Mut'ah University, Mut'ah, Jordan.

[6] Al-wa'elly, S. (2017). Involvement of Arabic language grammar book for the tenth-grade students in Jordan (An analytical study). Al-Ustath Journal, 2 (223), 69-90.

[7] Azar, F.E. (1982). Analysis of science textbook used in Iranian upper secondary school. Doctoral dissertation. The University of Illinois at Urbana. Dissertation Abstract International, 42 (09), 3945-A.

[8] Delavar, A. (2007). Theoretical and Practical Foundations of Research in Humanities and Social Sciences. Tehran: Roshd.

[9] Eisner, E.W. (1994). The educational imagination. New York. Macmillan Publishing Co. Inc.

[10] Eslaminejad, T., \& Saeid, N. (2017). Analysis of English language textbooks of the Iran language institute in order to specify the student's involvement index of the teaching-learning process. Modern Applied Science, 11 (4), 91-102.

[11] Fari, A. (2016). The extent of the general science books' contribution in the engagement of basic level students in learning from the point of view of teachers in Jenin Governorate. Unpublished Master Thesis, An-Najah National University, Nablus, Palestine.

[12] Fazlollahi, S., \& Tavana M. (2010). Methodology of content analysis techniques with an emphasis on text readability assessment and determination of the coefficient of conflict. Pazhuhesh, 2(1), 71-94.

[13] Haji, S. (2016). The degree of students involvement in the social studies textbook for six intermediate basic schools in the Kurdistan region study and analysis. The Eurasia Proceedings of Educational \& Social Sciences, (5), 328-338.

[14] Khalaf, M. (2015). Analytical study of the content of the book of science for the fourth grade in Jordan in the light of the development stage for students. Al-Manarah journal, 21(4), 197-230.

[15] Nawafleh, W. (2012). Involvement level for general science textbooks for intermediate basic school students in Jordan, AnNajah University Journal for Research, 26 (10), 2370-2398.

[16] Pamungkas, D. A. (2010). The quality of the English textbook used by international standard Junior high school. Unpublished Master Thesis, The State University of Malang, Indonesia.

[17] Romey, W. (1986). Inquiry techniques for teaching science. Prentice-Hall, Inc., Englewood Cliffs, New Jersey.

[18] Sa'ada, J., \& Ibrahim, A. (2011). The modern school curriculum. Dar Al Fikr, Amman, Jordan.

[19] Suleiman, I. (2003). Level of reading texts of the Arabic language book for the sixth grade in the province of Nablus. Unpublished Master Thesis, An-Najah National University, Nablus, Palestine.

[20] Tanner, D., \& Tanner, L. N. (1998). Curriculum development. Theory New York. Macmillan. Book company

[21] Yahia, S. (2014). Involvement of the science books for primary school students in Jordan. Journal of Educational Science, 22 (4), 60-87.

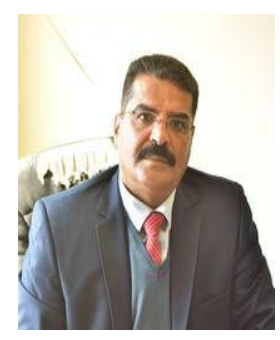

Yaser Aladwan is an assistant professor at the language center in the World Islamic Sciences and Education University, Amman, Jordan. His research focuses on TEFL and CALL. 